\title{
PENGETAHUAN IBU TENTANG KEPUTIHAN DI KOTA MANADO
}

\author{
${ }^{1}$ Emi Fadilla \\ ${ }^{2}$ Maya Mewengkang \\ ${ }^{2}$ John Wantania
}

\author{
${ }^{1}$ Kandidat Skripsi Fakultas Kedokteran Universitas Sam Ratulangi Manado \\ ${ }^{2}$ Bagian Obstetri dan Ginekologi Fakultas Kedokteran Universitas Sam Ratulangi Manado \\ Email: emifadilla@ymail.com
}

\begin{abstract}
Reproductive organs is one of the organs that are sensitive and require special care.Vaginal discharge is the health common problems of women genital area. The purpose of this research is to determine the knowledge of vaginal discharge and the relationship between the factors that affect the mother's knowledge about vaginal discharge .This research used observational analytic method with a cross sectional study trough primary data based on questionnaires. From 200 respondents, there were 7 respondents with a poor knowledge , 39 respondents with a moderete knowledge, and 154 respondents with a good knowledge. There is no significant relationship between mother's level of knowledge about vaginal discharge and age $(\mathrm{p}$-value $=0.171)$, education $(\mathrm{p}$-value $=0.090)$, resources $(\mathrm{p}$ value $=0.174)$ and experience ( $\mathrm{p}$ value $=0.052)$. There is a significant relationship between the level of knowledge about vaginal discharge and occupation ( $\mathrm{p}$ value $=0.000$ ). Mother's knowledge of vaginal discharge in manado city is good. In this research only occupation has a significant relationship with the level of knowledge about vaginal discharge.
\end{abstract}

Key words: vaginal discharge,knowledge

\begin{abstract}
Abstrak: Organ reproduksi merupakan salah satu organ tubuh yang sensitif dan memerlukan perawatan khusus. Masalah kesehatan area genital yang umum terjadi pada wanita adalah keputihan. Tujuan penelitian ini mengetahui pengetahuan ibu tentang keputihan dan hubungan antara faktor-faktor yang mempengaruhi tingkat pengetahuan ibu tentang keputihan.Penelitian ini menggunakan metode observasional analitik dengan studi cross sectional menggunakan data primer berdasarkan kuesioner.Dari 200 responden penelitian didapatkan 7 responden dengan pengetahuan kurang, 39 responden dengan pengetahuan cukup (sedang), dan 154 responden dengan pengetahuan baik. Tidak ada hubungan bermakna antara tingkat pengetahuan dengan umur (nilai $p=0,171$ ), pendidikan (nilai $p=0,090$ ), sumber informasi (nilai $p=0,174$ ) dan pengalaman ( nilai $p=0,052$ ). Ada hubungan yang bermakna antara faktor pekerjaan (dengan nilai $p=0,000$ ) dengan tingkat pengetahuan ibu tentang keputihan.Pengetahuan ibu tentang keputihan di kota Manado adalah baik. Pada penelitian ini hanya pekerjaan yang memiliki hubungan bermakna dengan tingkat pengetahuan ibu tentang keputihan.
\end{abstract}

Kata kunci: keputihan, pengetahuan.

Leukorrhea (white discharge, fluor albus, keputihan) adalah nama gejala yang diberikan kepada cairan yang dikeluarkan dari alat-alat genital yang tidak berupa darah. ${ }^{1}$

Keputihan merupakan keluhan umum, khususnya kalangan perempuan di Asia. Beberapa perempuan terganggu dengan keluarnya sedikit cairan sementara yang lainnya menganggap cairan lebih banyak keluar itu normal. Perempuan kadangkadang mengeluhkan keluarnya cairan putih atau cairan kental saat sebelum menstruasi atau pada pertengahan siklus. Cairan tersebut dapat berasal dari vagina, ovarium, saluran tuba atau paling sering serviks. ${ }^{2}$

Keputihan bukan suatu penyakit 
tersendiri, tetapi dapat merupakan gejala dari suatu penyakit lain. Keputihan yang berlangsung terus menerus dalam waktu yang cukup lama dan menimbulkan keluhan, perlu dilakukan pemeriksaan lebih lanjut untuk mengetahui sebabnya. Keputihan dapat disebabkan oleh berbagai hal, seperti infeksi mikroorganisme yaitu bakteri, jamur, virus, atau parasit. Juga dapat disebabkan oleh gangguan keseimbangan hormon, stres, kelelahan kronis, peradangan alat kelamin, benda asing dalam vagina, dan adanya penyakit dalam organ reproduksi seperti kanker leher rahim.Keputihan akibat infeksi sebagian besar penularannya melalui hubungan seksual. $^{3}$

Dalam kondisi normal, cairan lendir yang dikeluarkan oleh vagina berwarna putih, encer, tidak berbau, tidak menimbulkan keluhan, dan bila menempel pada celana dalam, warnanya menjadi kuning terang. Sebaliknya, bila terjadi gejala misalnya vagina terasa gatal, terbakar, kemerahan, nyeri selama berhubungan intim atau buang air kecil, keluar cairan berlebihan dari vagina (baik berlendir maupun bercampur darah), dan berbau, maka perlu di waspadai karena keputihan tersebut disebabkan oleh penyakit. $^{4}$

Menurut BKKBN (2009), di Indonesia sebanyak $75 \%$ wanita pernah mengalami Keputihanminimal satu kali dalam hidupnya dan 45\% diantaranya bisa mengalami keputihan sebanyak dua kali atau lebih. ${ }^{5}$

\section{METODE PENELITIAN}

Penelitian ini menggunakan desain penelitian observasional analitik dengan menggunakan rancangan cross sectional untuk mengetahui pengetahuan ibu tentang keputihan di kota Manado serta hubungannya dengan faktor-faktor yang mempengaruhi pengetahuan. Penelitian dilaksanakan pada bulan Oktober sampai bulan Desember 2013 di sepuluh kecamatan di kota Manado. Populasi penelitian adalah seluruh ibu yang tinggal di kota Manado.Teknik pengambilan sample yang digunakan adalah purposive sampling. Jumlah sampel yang diambil adalah 200 sampel.

\section{HASIL}

Hasil pengumpulan data dengan menggunakan kuesioner mengenai pengetahuan ibu tentang keputihan yang dibagikan kepada sebagian ibu yang berada dibeberapa Kecamatan dalam wilayah Kota Manado telah didapatkan 200 sampel.

Tabel 1. Distribusi responden berdasarkan pengetahuan Ibu pada beberapa Kecamatan di Kota Manado

\begin{tabular}{cccccc}
\hline No & Kec. & Kurang & $\begin{array}{c}\text { Pengetahuan } \\
\text { Cukup } \\
\text { (sedang) }\end{array}$ & Baik & total \\
\hline 1 & Malalayang & 2 & 7 & 11 & 20 \\
2 & Sario & 0 & 3 & 17 & 20 \\
3 & Wanea & 2 & 4 & 14 & 20 \\
4 & Wenang & 0 & 4 & 16 & 20 \\
5 & Tikala & 0 & 5 & 15 & 20 \\
6 & Paal 2 & 2 & 4 & 14 & 20 \\
7 & Mapanget & 0 & 4 & 16 & 20 \\
8 & Singkil & 1 & 4 & 15 & 20 \\
9 & Tuminting & 0 & 3 & 17 & 20 \\
10 & Bunaken & 0 & 2 & 18 & 20 \\
\hline & Total & $\mathbf{7}$ & $\mathbf{3 9}$ & $\mathbf{1 5 4}$ & $\mathbf{2 0 0}$ \\
\hline
\end{tabular}

Tabel 2. Distribusi responden berdasarkan kategori pengetahuan Ibu tentang keputihan di Kota Manado

\begin{tabular}{cccc}
\hline No & Pengetahuan & N & \% \\
\hline 1 & Kurang & 7 & 3,5 \\
2 & Sedang & 39 & 19,5 \\
3 & Baik & 154 & 77 \\
\hline & Total & $\mathbf{2 0 0}$ & $\mathbf{1 0 0}$ \\
\hline
\end{tabular}

Berdasarkan hasil penelitian didapatkan, 7 responden (3,5\%) dengan pengetahuan kurang, 39 reponden (19,5\%) dengan pengetahuan cukup (sedang), dan 154 responden (77 \%) dengan pengetahuan baik. 
Tabel 3. Hubungan umur dengan tingkat pengetahuan tentang keputihan
Pada Tabel diketahui IRT memiliki jumlah terbanyak untuk kategori pengetahuan baik. Hasil uji Chi Square didapatkan nilai $\mathrm{P}=0,000$.



\begin{tabular}{|c|c|c|c|c|c|c|c|c|c|c|c|}
\hline \multirow{3}{*}{$\begin{array}{c}<20 \\
20-30 \\
>30 \\
\end{array}$} & \multirow{3}{*}{$\begin{array}{l}1 \\
1 \\
5\end{array}$} & \multirow{3}{*}{$\begin{array}{c}1 \\
16 \\
22 \\
\end{array}$} & \multirow{3}{*}{$\begin{array}{c}8 \\
37 \\
109\end{array}$} & \multirow{3}{*}{$\begin{array}{r}10 \\
54 \\
136 \\
\end{array}$} & \multirow{3}{*}{\multicolumn{2}{|c|}{ keputihan den }} & \multirow{2}{*}{\multicolumn{3}{|c|}{ Pengetahuan }} & \multirow[b]{3}{*}{ Total } & \multirow[b]{3}{*}{$\mathbf{p}$} \\
\hline & & & & & & & & & & & \\
\hline & & & & & & & $\begin{array}{r}\text { Kura } \\
\text { ng }\end{array}$ & \multirow{2}{*}{$\begin{array}{c}\begin{array}{c}\text { Cukup } \\
\text { (Sedang) }\end{array} \\
13\end{array}$} & Baik & & \\
\hline Total & 7 & 39 & 154 & 200 & & Orang tua & 0 & & 28 & 41 & \multirow{6}{*}{0,174} \\
\hline & & & & & & Media & 2 & 11 & 56 & 69 & \\
\hline \multirow{4}{*}{\multicolumn{5}{|c|}{$\begin{array}{l}\text { Golongan umur lebih dari } 30 \text { tahun } \\
\text { memiliki jumlah terbanyak untuk kategori } \\
\text { pengetahuan baik. Hasil uji Chi Square } \\
\text { didapatkan nilai } \mathrm{P}=0,171 \text {. }\end{array}$}} & & $\begin{array}{l}\text { Tenaga } \\
\text { kesehatan }\end{array}$ & 0 & 5 & 25 & 30 & \\
\hline & & & & & & Teman & 3 & 5 & 24 & 32 & \\
\hline & & & & & & $\begin{array}{c}\text { Belum } \\
\text { pernah } \\
\text { mendengar }\end{array}$ & 2 & 5 & 21 & 28 & \\
\hline & & & & & & Total & 7 & 39 & 154 & 200 & \\
\hline
\end{tabular}

Tabel 4. Hubungan Pendidikan dengan Tingkat Pengetahuan tentang Keputihan

\begin{tabular}{|c|c|c|c|c|c|}
\hline \multirow[b]{2}{*}{ Kategori } & \multicolumn{3}{|c|}{ Pengetahuan } & \multirow[b]{2}{*}{ total } & \multirow[b]{2}{*}{$\mathbf{p}$} \\
\hline & Kurang & $\begin{array}{l}\text { Cukup } \\
\text { (Sedang) }\end{array}$ & Baik & & \\
\hline TS & 0 & 3 & 1 & 4 & \\
\hline SD & 3 & 6 & 40 & 49 & \\
\hline SMP & 3 & 12 & 43 & 58 & 0.090 \\
\hline SMA & 1 & 17 & 59 & 77 & \\
\hline PT & 0 & 1 & 11 & 12 & \\
\hline Total & 7 & 39 & 154 & 200 & \\
\hline \multicolumn{6}{|c|}{$\begin{array}{l}\text { Pada Tabel diketahui ibu lulusan SMA } \\
\text { memiliki jumlah terbanyak untuk kategori } \\
\text { pengetahuan baik. Hasil uji Chi Square } \\
\text { didapatkan nilai } \mathrm{P}=0,090 \text {. }\end{array}$} \\
\hline \multicolumn{6}{|c|}{$\begin{array}{l}\text { Tabel 5. Hubungan Pekerjaan dengan Tingkat } \\
\text { Pengetahuan tentang Keputihan }\end{array}$} \\
\hline \multirow[b]{2}{*}{ Kategori } & \multicolumn{3}{|c|}{ Pengetahuan } & \multirow[b]{2}{*}{ total } & \multirow[b]{2}{*}{$\mathbf{p}$} \\
\hline & $\begin{array}{c}\text { Kura } \\
\text { ng }\end{array}$ & $\begin{array}{c}\begin{array}{c}\text { Cukup } \\
\text { (sedang) }\end{array} \\
\end{array}$ & Baik & & \\
\hline IRT & 5 & 33 & 124 & 162 & \\
\hline PNS & 0 & 1 & 4 & 5 & 0,000 \\
\hline Wiiraswasta & 1 & 5 & 26 & 32 & \\
\hline Lainnya & 1 & 0 & 0 & 1 & \\
\hline Total & 7 & 39 & 154 & 200 & \\
\hline
\end{tabular}

Ibu yang mendapatkan informasi dari media memiliki jumlah terbanyak untuk kategori pengetahuan baik. Hasil uji Chi Square didapatkan nilai $\mathrm{P}=0,000$.

Tabel 7. Hubungan pengalaman dengan tingkat pengetahuan tentang keputihan

\begin{tabular}{cccccc}
\hline \multirow{2}{*}{ Kategori } & \multicolumn{3}{c}{ Pengetahuan } & & \\
\cline { 2 - 4 } & $\begin{array}{c}\text { Kura } \\
\text { ng }\end{array}$ & $\begin{array}{c}\text { Cukup } \\
\text { (Sedang) }\end{array}$ & Baik & total & $\mathbf{p}$ \\
\hline Diri sendiri & 5 & 31 & 136 & 172 & \\
Keluarga & 0 & 4 & 6 & 10 & \\
Teman & 1 & 3 & 11 & 15 & 0,052 \\
$\begin{array}{c}\text { Belum } \\
\text { pernah }\end{array}$ & 1 & 1 & 1 & 3 & \\
mengalami & & & & & \\
\hline Total & $\mathbf{7}$ & $\mathbf{3 9}$ & $\mathbf{1 5 4}$ & $\mathbf{2 0 0}$ & \\
\hline & & & & &
\end{tabular}

Jumlah terbanyak untuk kategori pengetahuan baik ada pada pengalaman diri sendiri. Hasil uji Chi Square didapatkan nilai $\mathrm{P}=0,000$.

\section{BAHASAN}

Berdasarkan hasil pada Tabel 1 diketahui ada beberapa kecamatan yang memiliki responden dengan pengetahuan kurang, diantaranya kecamatan Malalayang, 
Wanea, dan kecamatan Singkil. Hal ini karenasetiap kecamatan memiliki responden dengan karakteristik yang berbeda mulai dari umur, tingkat pendidikan, pekerjaan dan yang lainnya. Selain itu tingkat pemahaman setiap orang yang berbeda mempengaruhi tingkat pengetahuan dari masing-masing responden.

Pada Tabel 2 Dari data tersebut dapat kita lihat bahwa sebagian besar ibu di kota Manado memiliki pengetahuan yang baik tentang keputihan. Hal ini dikarenakan masalah kesehatan area genital yang umum terjadi pada wanita adalah keputihan, dan sebagian besar dari ibu sudah mendengar informasi tentang keputihan.

Pada Tabel 3 nilai $p=0,171$ maka $\mathrm{H}_{0}$ diterima, yaitu tidak terdapat hubungan yang signifikan antara faktor umur dengan tingkat pengetahuan ibu tentang keputihan.

Pada Tabel 4, dengan nilai $p=0,090$. maka $\mathrm{H}_{0}$ diterima, yaitu tidak terdapat hubungan yang signifikan antara faktor pendidikan terakhir dengan tingkat pengetahuan ibu tentang keputihan. Menurut Notoatmodjo Tingkat pendidikan menentukan mudah tidaknya seseorang menyerap dan memaknai pengetahuan yang diperoleh. ${ }^{6}$ Sebagian besar responden telah mengenyam pendidikan baik SD, SMP, SMA, dan perguruan tinggi, dan banyak responden yang memiliki pengetahuan baik. Namun, berdasarkan data di atas dapat kita lihat bahwa responden yang tidak bersekolah juga memiliki pengetahuan yang cukup hingga baik. Ini menunjukan bahwa bukan berarti seseorang yang berpendidikan rendah mutlak berpengetahuan rendah pula. Mengingat bahwa peningkatan pengetahuan tidak mutlak diperoleh dari pendidikan formal saja, akan tetapi dapat diperoleh melalui pendidikan nonformal.

Pada Tabel 5 dengan nilai $p=0,000$. $\mathrm{H}_{0}$ ditolak , untuk itu terdapat hubungan yang signifikan antara faktor pekerjaan dengan tingkat pengetahuan ibu tentang keputihan. Seperti halnya yang diungkapkan oleh Mubarak lingkungan pekerjaan dapat menjadikan seseorang memperoleh pengalaman dan pengetahuan baik secara langsung maupun tidak langsung. ${ }^{7}$
Pada Tabel 6, nilai $p=0,174$. maka $\mathrm{H}_{0}$ diterima, maka tidak terdapat hubungan yang signifikan antara informasi dengan tingkat pengetahuan ibu tentang keputihan. Pada Tabel 7 , nilai $p=0,052$. maka $\mathrm{H}_{0}$ diterima, yaitu tidak terdapat hubungan yang signifikan antara faktor pengalaman dengan tingkat pengetahuan ibu tentang keputihan. Sedangkan menurut Notoatmodjo penge-tahuan pada dasarnya terdiri dari sejumlah fakta dan teori yang memungkinkan seseorang untuk dapat memecahkan masalah yang dihadapinya. Pengetahuan tersebut diperoleh baik dari pengalaman langsung maupun melalui pengalaman orang lain. ${ }^{8}$

\section{SIMPULAN}

Pengetahuan tentang keputihan pada sebagian besar ibu di kota Manado adalah baik. Pada penelitian ini hanya pekerjaan yang memiliki hubungan bermakna dengan tingkat pengetahuan ibu tentang keputihan.

\section{SARAN}

Tingkatkan edukasi tentang keputihan dari dokter maupun petugas kesehatan agar masyarakat khususnya perempuan dapat membedakan antara keputihan yang fisiologis dan patologis. Perlu dilakukan penelitian lebih lanjut dengan mempertimbangkan jumlah pengambilan sampel yang lebih besar, persebaran sampel dan wilayah yang lebih luas untuk mengkaji pengetahuan ibu tentang keputihan serta hubungannya dengan faktor-faktor yang mempengaruhi pengetahuan.

\section{DAFTAR PUSTAKA}

1. Hutabarat H.Radang dan Beberapa Penyakit Penyakit lain pada Alat-Alat Genital Wanita. Jakarta: Bina Pustaka Sarwono Prawirohardjo; 2008.

2. RC Fernandopulle. An overview on approach to diagnosis and management of vaginal discharge in gynaecological practice, Srilanka Journal of Obstetric and Gynaecology 2012. 
3. Shadine M. Penyakit Wanita Pencegahan \& Deteksi dini. Yogyakarta: Citra Pustaka; 2012.

4. Aulia. Serangan Penyakit-Penyakit Khas Wanita. Jogjakarta: Buku Biru; 2012.

5. Nanlessy DM. Hubungan Antara Pengetahuan dan Perilaku Remaja Puteri Dalam MenjagaKebersihan Alat Genitalia Dengan Kejadian Keputihan Di SMA Negeri 2 Pineleng. Program Studi Ilmu Keperawatan
Fakultas Kedokteran Universitas Sam Ratulangi Manado; 2013.

6. Notoatmodjo S. Promosi Kesehatan \& Ilmu Perilaku. Jakarta: Rineka Cipta; 2007.

7. Mubarak WI. Ilmu Kesehatan Masyarakat Teori dan Aplikasi. Jakarta: Salemba Medika; 2009.

8. Notoatmodjo S. Metodologi Penelitian Kesehatan edisi revisi 2010. Jakarta: Rineka Cipta; 2010. 